\title{
Browsing regime and growth response of Abies alba saplings planted along light gradients
}

\author{
Andrea D. Kupferschmid • Ulrich Wasem • \\ Harald Bugmann
}

Received: 2 September 2013/Revised: 24 June 2014/Accepted: 28 July 2014/Published online: 18 August 2014

(C) Springer-Verlag Berlin Heidelberg 2014

\begin{abstract}
Silver fir is a highly desirable species in European mountain forests from a management and conservation point of view, but it is also highly palatable for ungulates. We planted Abies alba saplings along natural light gradients to explore under natural browsing: (1) the light conditions under which saplings grow best in the absence of browsing; (2) when and by which ungulate species which saplings are browsed; and (3) under which conditions saplings react most vigorously to browsing. The experiment was carried out in a Swiss forest using four fenced plots each containing about 30 saplings planted in 2001, which were between 17 and $100 \mathrm{~cm}$ tall in 2009. For half of the saplings, browsing was allowed and filmed from April 2009 to January 2010. Saplings grew better with more light (13\% rather than $10 \%$ canopy openness). Browsing was not a single event per sapling but a continuous process during the winter months. Almost all saplings exposed to browsing suffered heavy browsing by chamois and red deer, but no roe deer browsing was observed. The remainder of the browsed shoots were longer and contained more buds under $13 \%$ canopy openness. The browsinginduced height differences between browsed and
\end{abstract}

Communicated by G. Brazaitis.

Electronic supplementary material The online version of this article (doi:10.1007/s10342-014-0834-2) contains supplementary material, which is available to authorized users.

A. D. Kupferschmid · H. Bugmann

Forest Ecology, ITES, D-USYS, ETH Zürich, Zurich, Switzerland

A. D. Kupferschmid $(\bowtie) \cdot$ U. Wasem

Swiss Federal Institute for Forest, Snow and Landscape Research

WSL, Zuercherstr. 111, 8903 Birmensdorf, Switzerland

e-mail: andrea.d.kupferschmid@alumni.ethz.ch unbrowsed trees increased over time under all light conditions, and almost no diameter growth was measured in the years after browsing. In cases with severe browsing, management aimed at letting in more light does not lead to a substantially better tolerance of browsing. We thus recommend integrating the "feeding strength" in the assessment of browsing.

Keywords Ungulate browsing - Herbivory - Silver fir . Natural regeneration · Canopy openness

\section{Introduction}

Browsing by ungulates such as deer and chamois is one of many biotic factors that affect tree establishment, growth and mortality. Tree saplings are part of the normal food of ungulate species such as red deer (Cervus elaphus L.), roe deer (Capreolus capreolus L.) and chamois (Rupicapra rupicapra L.) (cf. Gebert and Verheyden-Tixier 2001; Tixier and Duncan 1996; Klötzli 1965; Cornelis et al. 1999; Onderscheka et al. 1989). European silver fir, Abies alba Miller, is among the most palatable tree species for ungulates in Europe (cf. Gill 1992; Klötzli 1965; Kupferschmid and Brang 2010). At the same time, A. alba is particularly valued in mountain protection forests because of its deep rooting system, which makes it less susceptible to storm damage, and because it is also less susceptible to beetle infestations than Picea abies (L.) Karst (Frehner et al. 2005).

Abies alba saplings, like many other species, grow better under good light conditions (Grassi and Bagnaresi 2001; Dobrowolska 2008). Such a pattern has also been found along light gradients from closed forest stands to windthrow gaps, but height growth seems to already peak at 
light levels with $10 \%$ canopy openness (Kupferschmid et al. 2013, 2014). Other studies have found that higher light levels, e.g. $>50 \%$ of above canopy light (Stancioiu and O'Hara 2006), $30 \%$ of canopy openness (Kučeravá et al. 2013) or $18 \%$ of open-field intensity (Robakowski et al. 2003), even negatively influence the height increment of A. alba saplings. Thus, low light levels can still result in strong growth in this shade-tolerant tree species, and many authors recommend regenerating firs under moderately shaded conditions (e.g. Kučeravá et al. 2013; Muscolo et al. 2010).

Nevertheless, A. alba has declined in abundance and distribution since about $1200 \mathrm{BP}$, primarily due to increases in human activities, including deforestation, forest burning and commercial forestry, as well as browsing by domestic and wild ungulates (Diaci et al. 2010; Feurdean and Willis 2008). In recent decades, failure in natural $A$. alba regeneration has often been blamed on ungulate (over)abundance, at least for larger height classes (cf. Weber 1967). This was attributed to selective browsing by ungulates (Klopcic et al. 2010) and the sensitivity of $A$. alba to the loss of its terminal shoot (cf. Senn and Suter 2003).

Clipping experiments showed a great variability in the response of $A$. alba saplings after terminal shoot reduction in winter, ranging from substantially decreased to increased tree height (Eiberle 1978; Häsler et al. 2008). In Kupferschmid and Bugmann' (2013) experiment, this variability was attributed to sapling vitality: fast-growing (dominant) saplings overcompensated for the height loss by "flagging up" a twig, while slow-growing (suppressed) saplings under moderate artificial shading showed reduced height. Furthermore, the timing of clipping also had considerable impact on the response and thus on the height of the trees at the end of the experiment (see Kupferschmid and Bugmann 2013). Summer browsing was found to have the most negative effect (Vandenberghe et al. 2008). Repeated clipping also had a negative impact (Ayres et al. 2004; Eiberle 1978).

How A. alba saplings react along natural light gradients to natural ungulate browsing is not clear. Under dark canopy conditions (less than about $10 \%$ canopy openness), small A. alba saplings did often not respond in the first year after browsing, but flagging occurred along the whole light gradient and led to height compensation (Kupferschmid et al. 2014). By comparing individual A. alba saplings in fenced vs. unfenced plots, Ammer (1996) found that, in unfenced plots, browsing reduced height under good light conditions, but not in shaded plots, and that height growth was not reduced by browsing on either site. Szymura et al. (2007) reported that the height increment of A. alba saplings was not correlated with light conditions and attributed this to the indirect effect of continuous browsing, which leads to higher A. alba mortality in more shaded places. However, in other studies, browsing-induced mortality on small $A$. alba saplings was not only higher under dark canopy conditions but also in small gaps than under moderately shaded conditions (i.e. $10-14 \%$ canopy openness, Kupferschmid et al. 2014; Kolly and Kupferschmid 2014).

Independent of light, the fastest growing A. alba saplings were browsed most strongly, leading to the paradoxical situation that the height growth of unbrowsed, suppressed saplings was still less than the overall height growth of browsed saplings (Kupferschmid et al. 2013). Häsler and Senn (2012) found that ungulates preferentially browsed A. alba saplings with long needles. Thus, it appears that the vitality of $A$. alba saplings has a double effect: on the one hand, sapling vitality influences the probability of being browsed (dominant rather than suppressed, cf. Plant Vigour Hypothesis by Price 1991), and on the other hand, sapling reaction to browsing is strongly influenced by vitality (cf. Kupferschmid and Bugmann 2013).

It is therefore not clear whether A. alba saplings can offset the height loss caused by natural browsing by specific responses and compensate fully, or whether the height difference remains or even increases over time. An experiment with natural browsing along natural light gradients but with even-aged planted saplings of known height would thus help to disentangle the impacts of ungulates, i.e. the selection of specific saplings by ungulates and the resilience of individual saplings after browsing.

We set up an experiment with even-aged planted A. alba saplings along natural light gradients around the light intensity at which height growth was found to peak and mortality was low, i.e. under moderately shaded conditions between 10 and $14 \%$ canopy openness. The specific objectives were to analyse: (1) the light conditions under which saplings grow best in the absence of browsing, (2) when and by which ungulate species which saplings are browsed and (3) under which conditions saplings react most vigorously to browsing.

\section{Methods}

Site

The mountain forest "Altenbann" (coordinates $46^{\circ} 59^{\prime} 00^{\prime \prime}$ I $9^{\circ} 05^{\prime} 07^{\prime \prime}$ ) is located on a hillslope above Schwanden, Canton Glarus (Switzerland), at about 995-1,020 m a.s.l. It faces north-east and has an inclination of $12-25^{\circ}$. A soil profile close to the experimental location revealed a humid cambisol (with a slight tendency towards an umbric regosol) with Verrucano bedrock (not limestone). The humus 


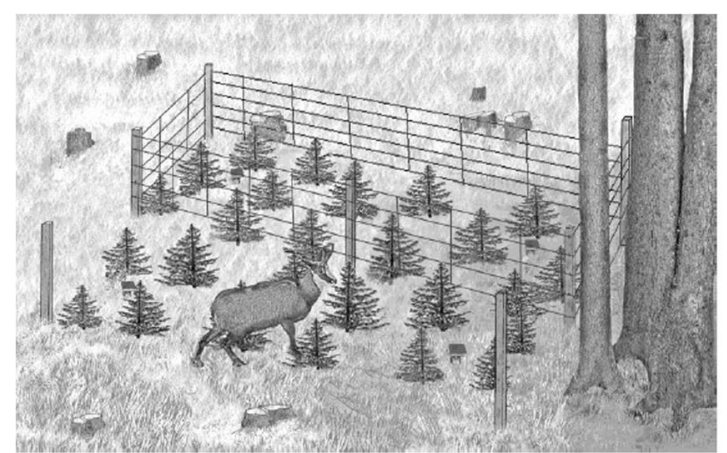

Fig. 1 Schematic representation of one plot used in the experiment during the opening time with a temporary fence between the control part and the part that was opened for browsing in 2009. Locations of temperature measurements and of "external" photographs are

form is moder, the clay content about $10 \%$ and the soil thus rather porous. There was no sign of waterlogging, and the water storage capacity amounts to only $7.8 \mathrm{~mm}$ as far as $24 \mathrm{~cm}$ soil depth and $84.7 \mathrm{~mm}$ as far as $100 \mathrm{~cm}$ soil depth, due to the low proportion of fine material between the stones. Thus, in spite of $1,600 \mathrm{~mm}$ precipitation per year (measured in Elm, distance ca. $6 \mathrm{~km}$, MeteoSchweiz 1998-2010), drought in the topsoil is a considerable risk.

Since 1548, the forest has been a part of the wildlife sanctuary "Freiberg Kärpf", which covers an area of $102 \mathrm{~km}^{2}$ with currently about 680 chamois, 173 red deer and 143 roe deer (counted in 1997, cf. Müller and Zopfi 1999). In recent years, there has been focused hunting to fight the infectious keratoconjunctivitis affecting chamois and to reduce the high ungulate-caused impact on tree regeneration (personal communication, F. Luchsinger, wildlife warden).

Tree plantation

In 2001, approximately 30-40 three-year-old Abies alba seedlings were planted in four fenced plots each measuring $5 \mathrm{~m} \times 5 \mathrm{~m}$. The provenance of the seeds was Chur Känzeli (a north-facing site at about 1,200 m a.s.l.). All fenced plots were placed so that just outside one side there were 1-3 large spruce trees (Picea abies). Some of the planted A. alba seedlings were thus under the canopy, some on the canopy edge and some in a gap (Fig. 1).

In July 2009, we took five fish-eye photographs $85 \mathrm{~cm}$ above the soil surface, four of them between the three most peripheral saplings towards each corner of the fenced plot and one at the centre of each plot (Fig. 1). We converted the pictures into black-and-white using the program Side Look (Nobis 2005) and calculated the canopy openness (i.e. the percentage of open sky seen from beneath a forest canopy given the additional influence of topographic shading) with the Gap Light Analyzer (GLA) software

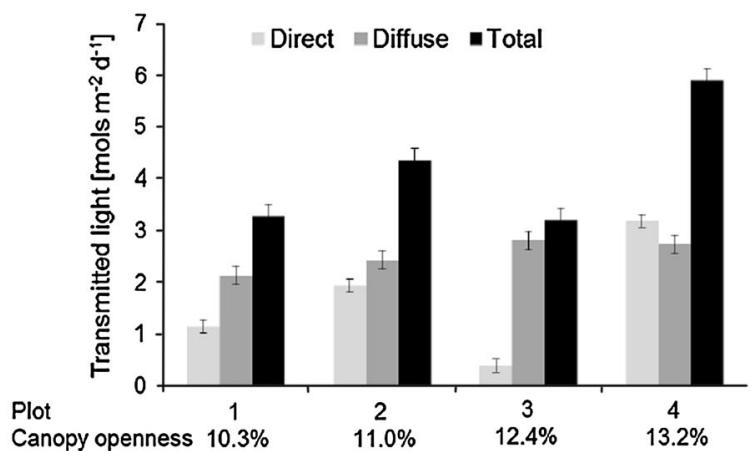

indicated with the wooden constructions to which the iButtons were attached. Right panel mean resulting direct or indirect transmitted light and standard deviation over the whole year in the four plots

(Cary Institute of Ecosystem Studies 1999). We also used GLA to estimate the diffuse and direct light for the entire year. The four fenced plots represent a light gradient from $10.3 \%$ on to $13.2 \%$ canopy openness (Fig. 1). As other differences, such as competition from tree roots or ground vegetation, may exist within each plot, we measured the distance to the nearest large spruce tree for every A. alba sapling as a proxy of such effects.

From fall 2008 to fall 2011, the air temperature $5 \mathrm{~cm}$ above the soil surface was measured using temperature loggers (DS1921G-F5\#, Thermochron ${ }^{\circledR}$ iButton, Maxim Integrated). To protect the loggers from direct sunlight, they were wrapped in aluminium foil and placed under a small wooden shelter (Fig. 1). The mean annual temperature was 6.2-6.9 ${ }^{\circ} \mathrm{C}$. Snow covered the site from about mid-November to March/April. Assuming that a constant daily temperature of zero indicates the presence of sufficiently deep snow cover to insulate the soil from the atmosphere, we estimated there were 110 days with deep snow cover in the winter 2008/09, 77 in 2009/10 and 60 in 2010/11. Furthermore, the annual degree-day sum (using a threshold temperature of $5{ }^{\circ} \mathrm{C}$ ) varied between 1,220 and $1,460{ }^{\circ} \mathrm{C}$ day.

As a measure for tree vitality, we analysed the concentration of elements in needles. In early July 2012, we harvested one twig of the third uppermost whorl from three control A. alba saplings out of each fenced plot. The needles from the years 2011 and 2012 were oven-dried separately at $65{ }^{\circ} \mathrm{C}$ to constant weight, weighed to an accuracy of $0.001 \mathrm{~g}$ and chemically analysed in the laboratory (method described in Kupferschmid et al. 2013).

At the beginning of the experiment in fall 2008, all $A$. alba saplings were measured to determine their height $\left(\mathrm{H}_{2008}\right)$, all height increments since they were planted on the site (e.g. $g_{2008}$ ), the total length of all side shoots and the length of all shoots formed in 2008. In addition, we counted the number of buds on the terminal shoot formed in 2008 . 


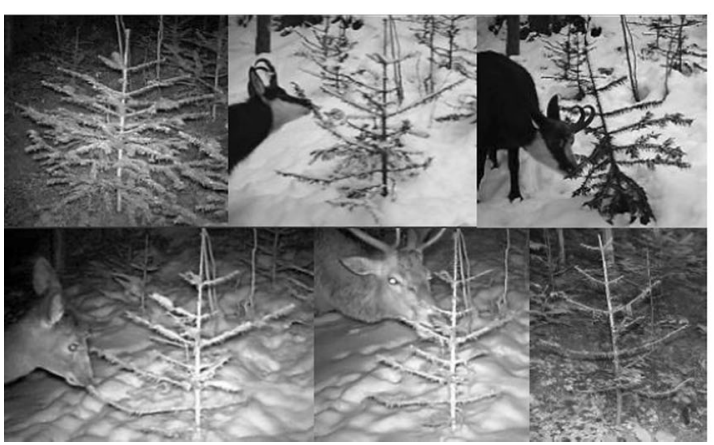

Fig. 2 Browsing by ungulates: Left panel: process of browsing; Abies alba sapling in plot 3 at 14 October 2009, after the fence had been opened, chamois browsing on December 15 and 17, and red deer browsing on January 7 and 9, when red deer finally browsed the terminal shoot of this sapling. The fence was closed on 12 January

\section{Browsing experiment}

Half of each fenced plot was opened on 16 April 2009 to allow chamois, roe and red deer to browse naturally (Fig. 1). Browsing activity was monitored by two infrared video-capable game cameras (Moultrie GameSpy I-60) per plot. We opened the fences shortly after snowmelt on 13 April 2009 when only a few A. alba saplings were still covered by snow, but observed practically no side shoot and absolutely no terminal shoot browsing until 2 July 2009. We therefore decided to close the fences in early July 2009 , so that all the shoots that had formed in 2009 could be measured. In addition, we measured stem diameter at the root collar (DRC, $2 \mathrm{~cm}$ above the soil surface) to an accuracy of $1 \mathrm{~mm}$.

On 14 October 2009, we reopened half of each fenced plot and closed them again on 12 January 2010, by which time most of the terminal shoots of the saplings had been browsed (e.g. Fig. 2). Again, browsing activity was monitored by two infrared game cameras per plot. In spring 2010 prior to the beginning of bud elongation, we measured tree height (Res_H ${ }_{2009}$ ), the length of the remaining terminal (Res_g) and of all 2009 shoots (Res_s) and counted the buds on the remaining piece of the terminal shoot and in the top whorl (bud). In fall 2010 and 2011, we remeasured all tree heights and shoot lengths. In addition, DRC was measured in 2011. We counted the number of terminal shoots (multiple terminal leaders) and determined the type of the highest terminal shoot after browsing, i.e. three reaction types were distinguished: (1) flagging up a twig, (2) new bud or shoot out of the remaining section of the terminal shoot or out of a twig whorl and (3) no reaction. In one plot (plot 4), a mature spruce had fallen in winter 2010/2011, so that 11 of the 16 control firs of that plot were browsed as well (but fortunately not the previously browsed firs).

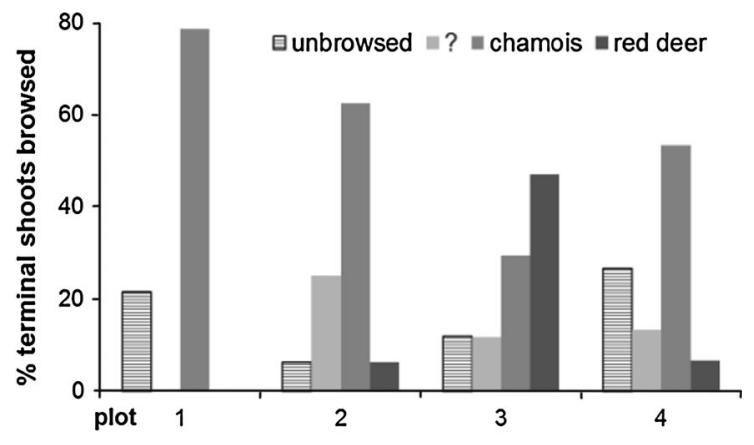

2010, and in fall 2010, the sapling was dead due to the combination of thrashing and heavy browsing (cf. Kupferschmid and Wasem 2014). Right panel reconstruction based on game camera movies of the ungulate species that caused the terminal shoot loss in the four plot parts that were opened for browsing in winter 2009/2010

Statistical analysis

To analyse the data, we adopted an a priori parsimonious model selection and inference using information-theoric criteria (cf. Stauffer 2008). This involved grouping the explanatory variables into light (canopy openness, diffuse light and direct light), height $\left(\mathrm{H}_{2008}-\mathrm{H}_{2011}\right.$ and $\left.\mathrm{Res} \mathrm{H}_{2009}\right)$ and diameter $\left(\mathrm{DRC}_{2009}\right.$ and $\left.\mathrm{DRC}_{2011}\right)$. Of each group, we included only one variable in any given statistical model, so as not to overfit the models with correlated variables. As only the mean and standard deviation of the light measurements per plot was calculated (cf. Fig. 1), we could not include the variable "plot" and light-related variables at the same time. Nevertheless, to capture some plot-dependent variability, we included the interaction term between the minimum distance to the nearest large spruce tree and the plot.

We fitted linear regression models using the "lm" procedure of the statistical software package R (version 2.15.0, R Development Core Team 2011). Variables and interactions with insignificant coefficients were removed from the model. The best candidate models were selected using the lowest Akaike's Information Criterion (AIC), together with the highest AIC weights, i.e. scaled likelihoods for the models, calculated according to the R package "MuMln" (method analogue chapter 5 in Stauffer 2008). All numeric response and explanatory variables were transformed using Tukey's first aid transformations, i.e. $\log _{10}$ for measured data and square root for counted data (Mosteller and Tukey 1977).

\section{Results}

Preface on mortality

In fall 2008, 108 A. alba saplings were still alive and six had been died (five of the latter were in plot 2). In autumn 2009, 

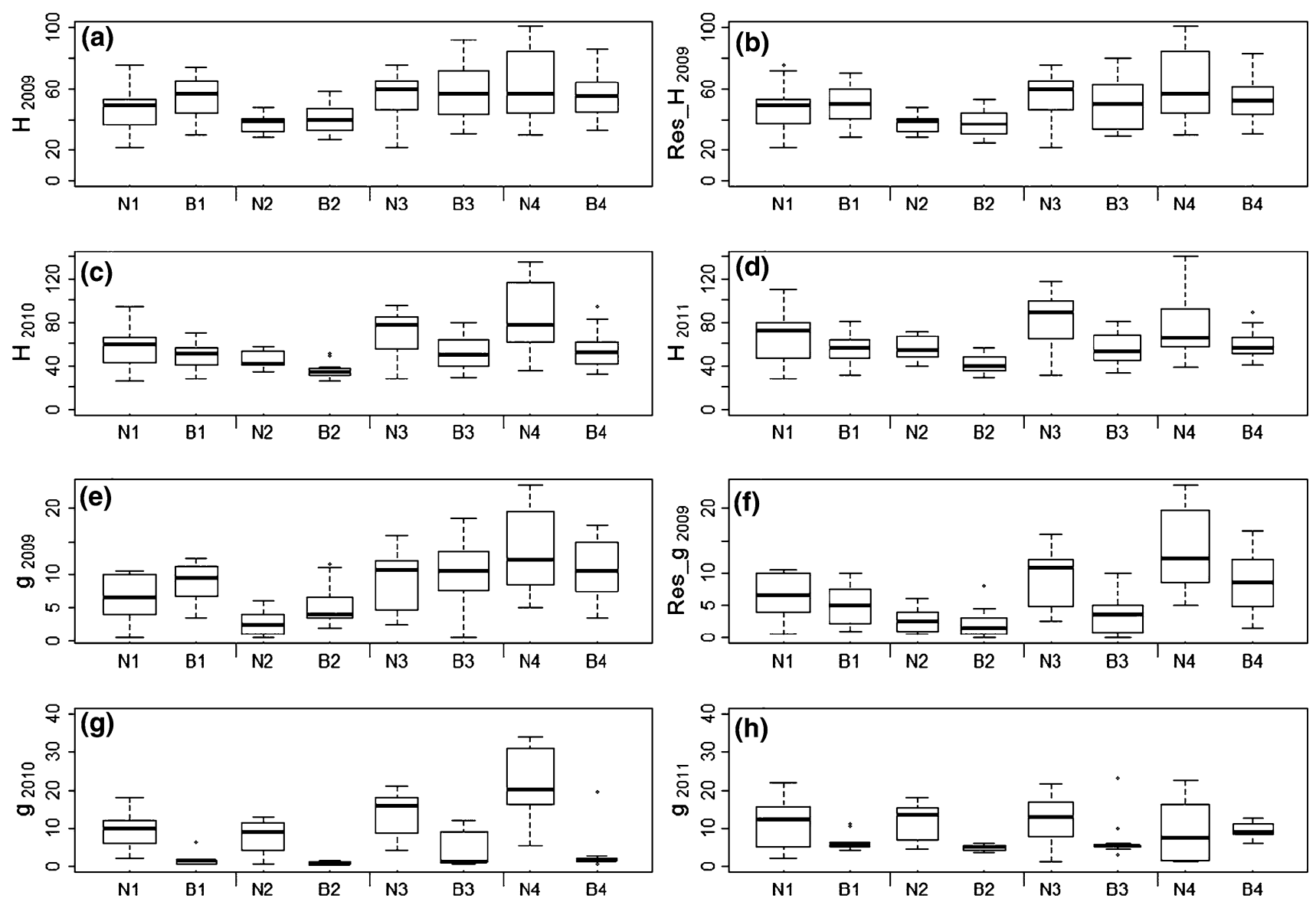

Fig. 3 Height and growth prior to and after ungulate browsing on planted Abies alba saplings. "N" refers to no browsing (i.e. the control trees), "B" to terminal shoot browsing in the winter $2009 / 2010$ and the number to the plots 1-4. a Height in fall 2009 before browsing $\left(\mathrm{H}_{2009}[\mathrm{~cm}]\right)$, b height directly after browsing in winter 2009/2010 (Res_H $\mathrm{H}_{2009}$ [cm]), c height one vegetation season after browsing in fall $2010\left(\mathrm{H}_{2010}[\mathrm{~cm}]\right)$, d height in fall $2011\left(\mathrm{H}_{2011}\right.$

two more saplings were dead, one of them in plot 2 , and the other had been removed by workers as it was damage when the fence was repaired. The fungus Phomopsis was isolated on the six A. alba saplings in plot 2 that died naturally, and on one sapling, Mollisia was also found but no traces of the fungus Armillaria or Heterobasidion. Phomopsis could have played a role in the trees' mortality, although it is usually only lethal if other stress factors are operating, i.e. it is a weak parasite after frost or drought. During the experimental period, mortality caused by chamois and red deer amounted to $4.7 \%$, i.e. two saplings due to browsing and three after additional red deer fraying who thrashed the trees with their antlers (Fig. 2 and Kupferschmid and Wasem 2014).

Under which light conditions do Abies alba saplings grow best in the absence of browsing?

The A. alba saplings were all planted in 2001, and thus of the same age. Nevertheless, their height increment and

[cm]), e terminal shoot growth in fall 2009 before browsing $\left(g_{2009}\right.$ [cm]), f residual 2009 terminal shoot length after browsing in winter $2009 / 2010$ (Res_g $\left.\mathrm{g}_{2009}[\mathrm{~cm}]\right), \mathbf{g}$ terminal shoot growth in $2010\left(\mathrm{~g}_{2010}\right.$ $[\mathrm{cm}])$, h terminal shoot growth in $2011\left(\mathrm{~g}_{2011}[\mathrm{~cm}]\right)$. Note that in plot 4 some browsing occurred in winter 2010/2011 on previously unbrowsed trees as a result of a fallen spruce tree; this explains the low values in $\mathrm{N} 4$ in $3 \mathrm{~d}$ and particularly in $3 \mathrm{~h}$ compared to $3 \mathrm{c}$ and $3 \mathrm{~g}$

height eight growing seasons after planting varied greatly within and between the plots. In fall 2009, when the fences were reopened, the $106 \mathrm{~A}$. alba saplings that were still alive were between 17 and $100 \mathrm{~cm}$ tall (Fig. 3a).

Within the small range of site openness in the study (cf. Fig. 1), it seems the more light available, the better the $A$. alba saplings grew prior to browsing, and the larger and thicker (DRC) they were in autumn 2009 (Fig. 3a, e; Table 1). The models for height and height increment in 2009 prior to browsing were slightly better if percentage site openness was used as a predictor variable (e.g. AIC 378.10 for $\mathrm{H}_{2009}$, cf Table 1) compared to those with only direct light (AIC -372.28) or diffuse light (AIC -373.81). Including the interaction term between the minimum distance to the nearest large spruce tree and the plot improved some, but not all models (cf. Table 1).

The needles from the unbrowsed control saplings in the fenced plot 4 that received the most light (cf. Fig. 1) were by far the heaviest $(0.5 \mathrm{~g}$ per 100 needles compared to 
Table 1 Results of linear regression models for Abies alba saplings before browsing: height in fall 2009 ( $\left.\mathrm{H}_{2009}\right)$, terminal shoot growth of the years $2008\left(\mathrm{~g}_{2008}\right)$ and $2009\left(\mathrm{~g}_{2009}\right)$ and diameter at root collar in $2009\left(\mathrm{DRC}_{2009}\right)$

\begin{tabular}{|c|c|c|c|c|c|c|c|c|}
\hline & $\mathrm{H}_{2009}^{\mathrm{a}}$ & & $\mathrm{g}_{2008}^{\mathrm{a}}$ & & $\mathrm{g}_{2009}^{\mathrm{a}}$ & & $\mathrm{DRC}_{2009}^{\mathrm{a}}$ & \\
\hline Intercept & $-0.401 \pm 0.102$ & $* * *$ & $-2.800 \pm 0.370$ & $* * *$ & $-5.075 \pm 2.321$ & $*$ & $-2.918 \pm 0.561$ & $* * *$ \\
\hline Canopy openness ${ }^{\mathrm{a}}$ & $0.416 \pm 0.093$ & $* * *$ & $1.053 \pm 0.336$ & $* *$ & $3.936 \pm 2.219$ & . & $1.486 \pm 0.536$ & $* *$ \\
\hline Min.distance ${ }^{\mathrm{a}}$-plot 4 & & ns & & ns & $-0.110 \pm 0.263$ & $\mathrm{~ns}$ & $0.034 \pm 0.064$ & ns \\
\hline Min.distance ${ }^{\mathrm{a}}$-plot 3 & & ns & & $\mathrm{ns}$ & $-0.280 \pm 0.231$ & ns & $0.049 \pm 0.056$ & ns \\
\hline Min.distance ${ }^{\mathrm{a}}$-plot 2 & & ns & & ns & $-0.376 \pm 0.200$ & . & $0.164 \pm 0.048$ & $* * *$ \\
\hline Min.distance ${ }^{\mathrm{a}}$-plot 1 & & ns & & ns & $0.150 \pm 0.253$ & ns & $0.119 \pm 0.061$ & . \\
\hline $\mathrm{H}_{2008}^{\mathrm{a}}$ & $1.017 \pm 0.029$ & $* * *$ & $1.519 \pm 0.156$ & $* * *$ & $1.079 \pm 0.250$ & $* * *$ & $0.867 \pm 0.060$ & $* * *$ \\
\hline Adjusted $R^{2}$ & 0.926 & & 0.695 & & 0.345 & & 0.738 & \\
\hline AIC & -378.10 & & -106.30 & & 67.59 & & -233.42 & \\
\hline
\end{tabular}

The number of observations in the analyses was 106

Significance code: $* * * p \leq 0.001$, $* * p \leq 0.01, * p \leq 0.05$, “." tendency with $p \leq 0.1$ and ns not significant

${ }^{a}$ Log transformed

$0.31-0.38$ in needles from saplings in fenced plots $1-3$ ). Two-year-old needles from the A. alba saplings in the fenced plot 4 also contained proportionally more nitrogen (1.78\% of dry weight compared to $1.43-1.58 \%$ in fenced plots $1-3)$. Little magnesium $(\mathrm{Mg})$ was found in the needles from the saplings in the fenced plots 2 and $4(0.05-$ $0.06 \%$ ) compared to saplings in the fenced plots 1 and 3 $(0.09-0.11 \%)$, and little calcium (Ca: $0.18 \%)$ and zinc (Zn: $17.13 \mathrm{ppm}$ ) in one-year-old needles from the saplings in the fenced plot 4 (additional data are given in Online Resource ESM_1).

When and by which ungulate species are which Abies alba saplings browsed?

No terminal shoots were browsed in spring and summer 2009 on the 62 A. alba saplings accessible to browsing during that time. The chamois and roe deer that triggered the game camera ate either Rubus sp. or Vaccinium myrtillus growing between the A. alba saplings (Kupferschmid and Wasem 2014), or they just sniffed the A. alba saplings. Only very occasionally were 14 trees browsed on a 2009 lateral shoot.

In fall 2009, after the first snowfall, browsing by chamois and red deer began first on the current-year lateral shoots, then on older lateral shoots and only later on the terminal shoots (see movies in Kupferschmid and Wasem 2014). This sequence occurred although many twigs had first to be dug out of the snow by the animals $(\mathrm{Ku}-$ pferschmid and Wasem 2014). Importantly, browsing on each sapling was not a single event. Rather, chamois (mostly an adult female with three kids) browsed during the day and a red deer during the night. This pattern continued for weeks (cf. Fig. 2 and the movie in Kupferschmid and Wasem 2014).
Based on photos and movies obtained with the game cameras, we reconstructed which ungulate species had browsed the terminal shoots of which A. alba saplings (Fig. 2). The browsers of some A. alba saplings could not be identified (cf. ? in Fig. 2) as the game cameras have a short-time delay between the detection of an animal and the beginning of the recording, and there is a minimum delay of $1 \mathrm{~min}$ between two consecutive films. No roe deer was observed browsing on shoots of the A. alba saplings. Chamois browsed the most terminal shoots except in plot 3 , where red deer browse was more frequent (cf. Fig. 2). Ten A. alba saplings that were accessible to browsing after part of fence had been opened were not browsed, and these saplings are included in the unbrowsed trees in the statistical analysis. More than only the last terminal shoot was browsed on just four trees.

The remaining lengths of all 2009 shoots were significantly greater, the larger the tree had been prior to browsing $\left(\log _{10}(\right.$ Res_s $)=0.457 \pm 0.031 \times \log _{10}\left(\mathrm{H}_{2009}\right)$, $\mathrm{AIC}=36.02)$, and thus the greater the site openness $\left(\log _{10}(\right.$ Res_s $)=0.727 \pm 0.05 \times \log _{10}$ (canopy openness), AIC $=36.98)$. The remaining terminal shoot section was longer, the larger the tree had been prior to browsing, and also if it had been browsed by an "unknown" animal (Res_g in Table 2). The taller the tree was prior to browsing, the more buds remained after browsing on the residual terminal shoot sections and on the lateral shoots of the uppermost whorl (Fig. 4a; Table 2).

\section{Which Abies alba saplings react best after browsing?}

Of the surviving A. alba saplings, only one browsed sapling in plot 4 failed to form a new terminal shoot by the end of the second growing season after browsing. All other saplings reacted by producing a new shoot either out of the 


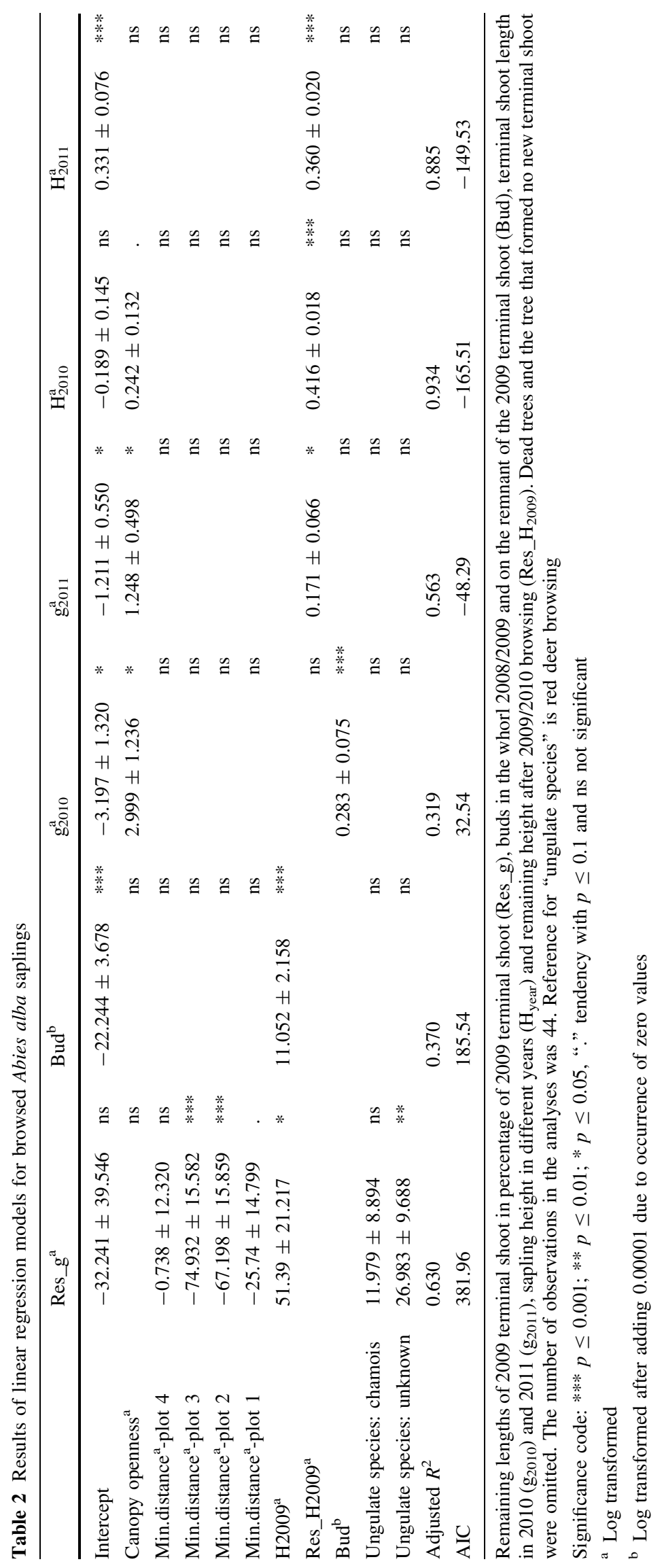



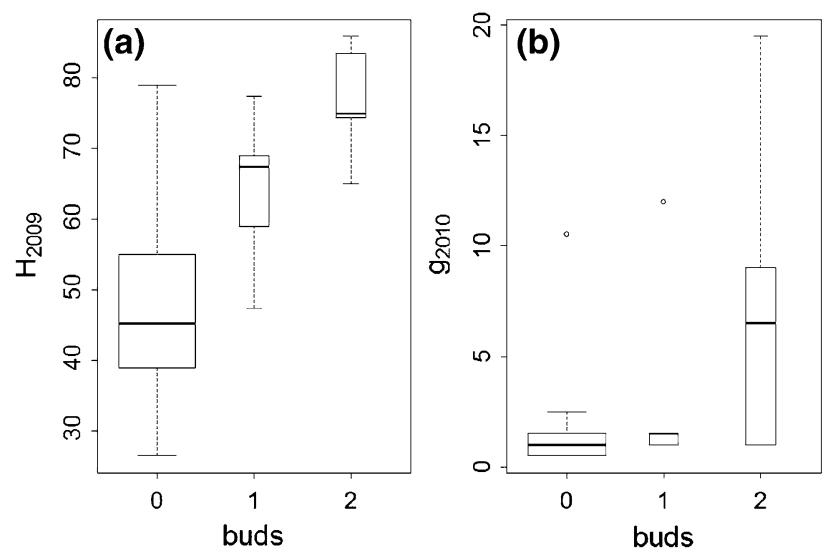

Fig. 4 Relationship between buds on the remaining piece of 2009 terminal shoot after browsing in winter 2009/2010 and a the tree height in fall 2009 before browsing $\left(\mathrm{H}_{2009}[\mathrm{~cm}]\right)$, and $\mathbf{b}$ the terminal shoot growth 2010 after browsing $\left(\mathrm{g}_{2010}[\mathrm{~cm}]\right)$

uppermost whorl or out of the section of the terminal shoot remaining after the 2009/2010 browsing. That is, no flagging occurred.

Browsed A. alba saplings grew better in the first growing season after browsing $\left(\mathrm{g}_{2010}\right)$ if they had more light and more buds remaining on the residual section of the 2009 terminal shoot (bud), regardless of their height (Table 2; Fig. 4b, excluding all the dead saplings and the sapling that had not yet reacted). In the second growing season after browsing, the browsed saplings grew better the more light they had and the taller they had been after browsing $\left(\mathrm{g}_{2011}\right.$ in Table 2). This applied regardless of which ungulate species had browsed, how many buds had remained on the 2009 terminal shoot piece or whether the new shoot came out of the whorl or distally out of the remaining section of the 2009 terminal shoot. The height of the browsed saplings one growing season after browsing $\left(\mathrm{H}_{2010}\right)$ was greater the more light was available and the larger the tree had been after browsing. The height two seasons after browsing $\left(\mathrm{H}_{2011}\right)$ even depended on sapling height alone (Table 2).

Comparing the height in 2010 and 2011 of all living $A$. alba saplings, the browsed saplings were shorter than unbrowsed ones (Table 3; Fig. 3c, d). This also applied to the height increments of 2010 and 2011 (Table 3, Fig. 3g, h). A. alba saplings that had been browsed on their terminal shoot were not even able to partially compensate, i.e. even 2 years after browsing they did not achieve the same terminal shoot length as unbrowsed saplings (Fig. 3h). Thus, browsing-induced height differences increased greatly over time (compare Fig. 3b with 3d).

Stem diameter at the root collar (DRC) in 2011 was smaller for browsed than unbrowsed A. alba saplings, but larger the longer the distance to the nearest large spruce

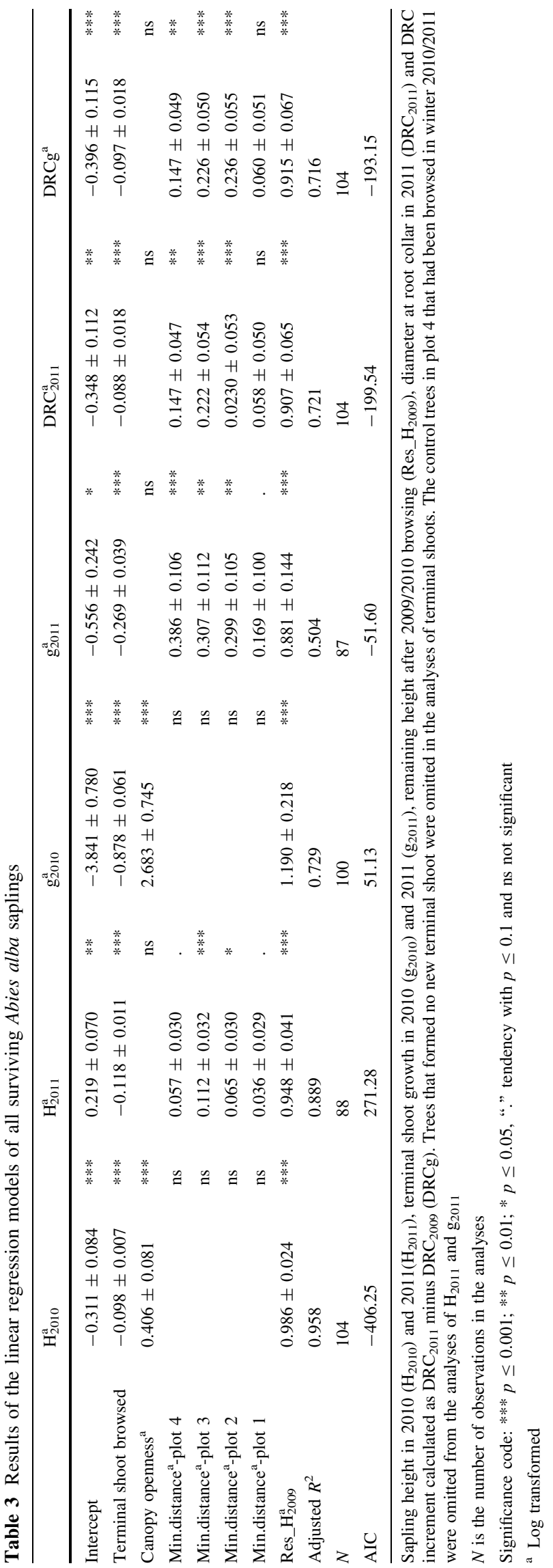




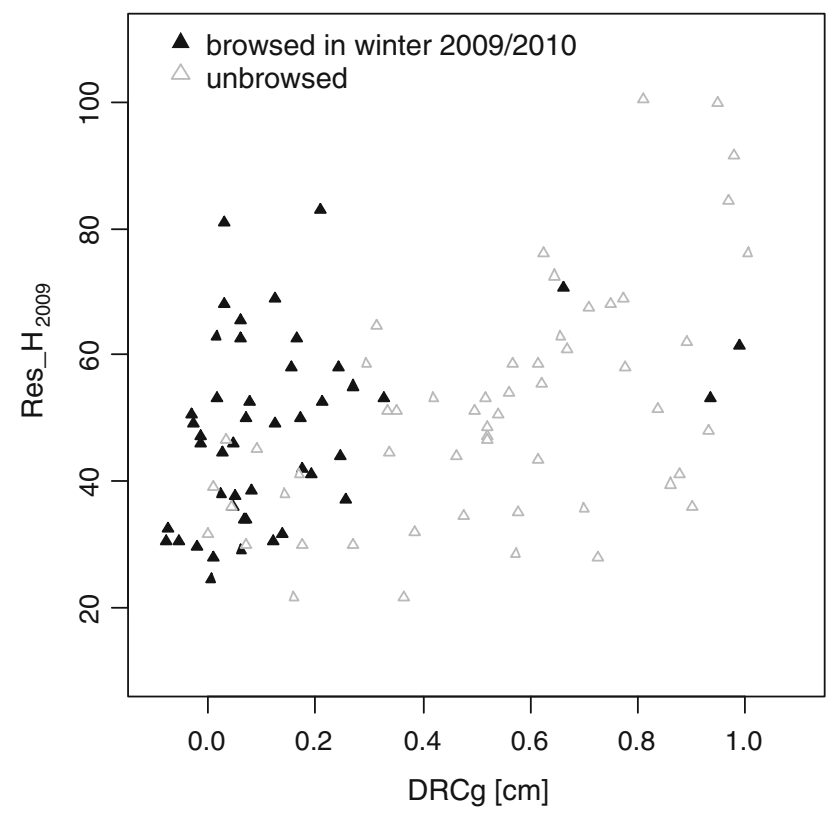

Fig. 5 Relationship between the tree height in spring 2010 after browsing in winter 2009/2010 (Res_H ${ }_{2009}$ [cm]) and the increment in diameter at the root collar (DRCg), calculated as $\mathrm{DRC}_{2011}$ minus $\mathrm{DRC}_{2009}$ for browsed and unbrowsed Abies alba saplings

tree and the taller the sapling was after browsing (Table 3). Browsed trees grew hardly at all in diameter. Therefore, diameter growth from 2009 to $2011\left(\mathrm{DRC}_{\mathrm{g}}\right)$ was much lower for browsed than unbrowsed saplings (Fig. 5; Table 3).

About three quarters of the browsed saplings became forked or had multiple leaders. In total, 11 saplings had one terminal shoot, 20 two and 15 three terminal shoots after browsing, while only one unbrowsed sapling became forked.

\section{Discussion}

Under which light conditions do Abies alba saplings grow best in the absence of browsing?

We had planted the A. alba saplings along natural light gradients around the light intensity at which height growth was found to peak, i.e. 10-14\% canopy openness (Kupferschmid et al. 2013, 2014). Height growth and needle weight were generally better the more light was available. However, the variability in height was large and the shadetolerant $A$. alba saplings grew relatively well with little light, with the exception perhaps of plot 2 (cf. Fig. 3).

Naturally grown, i.e. unfertilised A. alba saplings, can most likely be considered healthy if their needle elements exceed the concentrations specified in guidelines regarding the desirable nutrient concentrations for Christmas plantations of A. alba (Mutch 2000) or other Abies saplings (Hart et al. 2012). Indeed, this was the case for all elements except magnesium in the needles of saplings in the fenced plots 2 and 4 and for $\mathrm{Ca}$ and $\mathrm{Zn}$ in the fenced plot 4 , where the values were slightly below the recommended values. Magnesium concentrations of A. alba saplings on other sites in Switzerland were found to be similar to those in our fenced plots 1 and 3 (Kupferschmid et al. 2013). As magnesium is important for photosynthesis, this could explain the relatively low growth rates in our plot 2, but the growth rate in plot 4, which had the most available light, was the highest.

Among the planted saplings in the four plots (ca. $100 \mathrm{~m}^{2}$ ), only six A. alba saplings naturally established from 2001 to 2012. In addition, there was a high mortality of saplings due to weak parasitic fungi, particularly in plot 2. This raises the question whether soil-related limitations might be responsible for low establishment, low growth and high mortality (cf. discussion in Paluch 2005). The soil data clearly revealed a higher potential drought risk in the upper soil horizon than at other Swiss sites that feature abundant A. alba regeneration (Kupferschmid et al. 2013). Fir establishment was found to be positively influenced by air humidity (Gabellini and Screm 1968), and edaphic conditions could result in the elimination of superficially rooted seedlings (Tan and Bruckert 1992). Shielding from wind has also been found to enhance fir establishment (Weber 1967). As our site is located in the northern PreAlps of Switzerland, strong warm-dry downslope winds (foehn) are frequent and may sometimes dry out the upper soil horizon. In addition, the humus form of the study site is a moder and $\mathrm{pH}$ was low. Neither of these factors are conducive to fir regeneration (Priewasser et al. 2013; Ignesti and Paci 1990).

To conclude, fir saplings under moderate light levels grew better with $13 \%$ than with $10 \%$ canopy openness, but vitality, as measured through element concentration of elements in the needles, did not tend to be enhanced.

When are Abies alba saplings browsed?

Eight years after planting, we exposed half of the A. alba saplings to natural ungulate browsing. Surprisingly, no browsing occurred in spring before budburst and during the first growing season, but only after the first snow cover in the winter. Although this may have been a coincidence, the following factors may have played a role:

1. Snow melt in spring in 2009 took place very rapidly as temperatures were unusually high, thus many chamois may have moved immediately to higher regions and were not present near the experimental site. 
2. Chamois browsed on A. alba regeneration mostly during winter (cf. the four plots in 2009/2010 and the plot 4 in 2010/2011).

3. Red deer were apparently not in the area during spring and summer and the few roe deer present showed no interest in A. alba but preferred to browse on blackand blueberry bushes (Kupferschmid and Wasem 2014).

4. Human disturbance may have deterred the ungulates, as all saplings were checked weekly for browsing, sometimes with accompanying dogs (belonging to the rangers).

However, in a study in some windthrow areas in Switzerland, coniferous saplings (Abies alba and Picea abies) were selected in both summer and winter and browsed according to availability in spring (Moser et al. 2006). There, Rubus spp. was also consumed mostly by roe deer (Moser et al. 2006). Analysing the content of roe deer rumen, winter feeding on coniferous saplings was more frequent than feeding during the growing season, but bits of coniferous tissue were found in their rumen in every season (Tixier and Duncan 1996; Cornelis et al. 1999). The same was found for red deer and chamois (Onderscheka et al. 1989). According to Häsler and Senn (2012), A. alba consumption by red and roe deer continuously decreased from winter to spring until fall, unlike for chamois, where it was at one site highest in summer. In contrast, other studies have found A. alba saplings tend to be browsed during certain periods only, for example: only in winter (September to April) by chamois in the Spanish Pyrenees (Garcia-Gonzalez and Cuartas 1996), or before bud break of A. alba (Saint-Andrieux et al. 1999 cited in Pépin et al. 2006). In another study, roe deer were found to prefer A. alba saplings in May, but browsing was frequent from January until May (Klötzli 1965). Places with early snow melt appear to be more prone to chamois browsing (Kupferschmid and Bugmann 2005). Odermatt and Wasem (2008) repeatedly observed that browsing took preferentially place between snowmelt and the beginning of bud elongation in spring, which is exactly the time when we opened the fences.

Based on our results, we conclude that terminal shoot browsing on A. alba saplings occurs mostly during periods of little snow in winter, but not or at least less often during the growing season.

Which ungulate species browse Abies alba saplings?

Only chamois and red deer browsed the terminal shoots of the A. alba saplings in our experiment. Roe deer probably avoid sites where red deer are present.

Browsing by red deer tends to be more intensive than by chamois. Shipley et al. (1999) found that the diameter at which the shoots were bitten off was clearly smaller for roe deer than for red deer and moose (Alces alces). Chamois's body size and feeding behaviour are more similar to those of roe than to those of red deer. Therefore, larger bites from red deer than from chamois could be expected. However, roe deer seem to often consume only the buds of A. alba saplings (Kupferschmid et al. 2013), whereas chamois browse large parts of the terminal and lateral shoots, if they are repeatedly browsing on the same tree (as in our experiment). Red deer are even more likely to browse large parts or whole shoots, which leads to greater "feeding strength" and thus heavier impact on the saplings.

Which Abies alba saplings are browsed?

Ungulates probably choose trees as a food patch according to morphological features (Iason et al. 1996). Larger saplings with a large crown volume are more likely to be browsed by deer (Häsler and Senn 2012; Kupferschmid et al. 2013; Iason et al. 1996). They are typically browsed for longer periods with more offtake than smaller or less bushy saplings (Iason et al. 1996; Danell et al. 1994). Thus, ungulates consume more tissue from larger saplings (Shipley et al. 1999). In our study, the remaining length of the current years' terminal shoot was larger, the taller the saplings had been prior to browsing (Table 2). Thus, larger A. alba saplings remained larger even after heavy browsing.

Which Abies alba saplings react best after browsing?

We found that the A. alba regeneration in our study could not even partially compensate for the height loss caused by browsing. The A. alba saplings that had been browsed on their terminal shoot did not have the same height increment as unbrowsed trees even 2 years after browsing, and thus the browsing-induced height difference became even larger over time (Fig. 3). Similarly, the growth in stem diameter appears to be strongly reduced by heavy browsing (Fig. 5). No compensation has also been found for A. alba saplings after heavy and repeated clipping (Eiberle 1978; Ayres et al. 2004).

Flagging up a side shoot to form a new leader shoot was the best reaction for an A. alba sapling to ensure future growth in clipping experiments, in particular when growing in full sun (Häsler et al. 2008). This led to overcompensation in the most vigorously growing trees (Kupferschmid and Bugmann 2013). Pinus sylvestris saplings that had been clipped directly below the uppermost whorl typically reacted by flagging and thus lost only about the equivalent of one annual height increment, while saplings where all current shoots of the second uppermost whorl had been additionally clipped reacted with distal epicormic shoots 
and lost the equivalent of two annual height increments (Långström and Hellqvist 1992). Not a single tree in our experiment was able to react by flagging up an existing shoot, probably because all annual shoots of the upper whorls had been browsed (e.g. Fig. 2).

This suggests that the amount of tissue eaten, i.e. "feeding strength", is at least as important for the reaction of A. alba saplings to browsing as site or environmental conditions.

The intensive browsing of saplings at our study site meant that they lost most of their reserves, as coniferous evergreen species store the greater part of the nutrients in the most recent needle generations (Chapin et al. 1980; Millard et al. 2001). In addition, the majority of nitrogen for leaf growth in spring is usually mobilised from the reserves (cf. Millard 1995). Hence, the A. alba saplings in the present experiment first had to produce new adventitious buds in the first year (mostly on the uppermost bud whorl) using their small amount of residual reserves. We therefore detected almost no height and diameter increment after browsing. Typically, it took another year for the saplings to produce a real new terminal shoot. This finding was confirmed at three other sites in Switzerland, where half of the A. alba saplings produced only a new terminal bud in the first year (Kupferschmid et al. 2013). Thus, our results affirm that $A$. alba tend to react with delay to leader shoot lost (Osterloher and Wiechmann 1993), at least after intensive browsing.

Abies alba saplings reacted to browsing by producing a new shoot in the first year only if buds were already present on the residual section of the terminal shoot. If more light was available, more buds remained on the residual section of the terminal shoot and in the uppermost whorl (cf. our study and Kupferschmid and Bugmann 2013). Thus, the saplings had more options to react with shoots out of regular lateral buds (Häsler et al. 2008), and the terminal shoot increments after browsing were larger. Nevertheless, the inability of $A$. alba saplings to compensate for height loss was independent of light in our study, in contrast to in clipping experiments. In general, it is assumed that sapling response depends on the type of tissue removed and less on the total biomass lost (Baraza et al. 2007). For example, for Acer saccharum, clipping promoted the elongation of regular lateral buds into new leader shoots of the same length (i.e. partial height compensation due to equal growth) if the clipping of leader shoots included several lateral buds. No such compensation occurred, however, if only a very small fraction or almost all of the annual leader shoot was removed (Metzger 1977).

Thus, the availability of intact twigs and the amount and distribution of buds along the leader shoot play a crucial role in determining the compensation capacity of tree saplings after browsing.
Irrespective of light availability, approximately $75 \%$ of all A. alba saplings browsed in our experiment formed several new leader shoots. Multi-trunking due to the loss of apical dominance has often been reported (Mitscherlich and Weise 1982; Bergquist et al. 2003; Långström and Hellqvist 1992). For forest management, the development of multi-trunking is probably an as serious consequence of browsing as delayed and reduced height growth (Welch et al. 1992).

\section{Conclusion}

Browsing by chamois and red deer on tree saplings such as Abies alba is part of natural ecosystem dynamics. "Feeding strength"-i.e. the amount of tissue ungulates eat such as terminal buds, part(s) of the annual terminal shoot, the entire whole annual shoot or the drastic curtailment of much more than just the annual shoots-appears to vary with the browsing species (roe deer $<$ chamois $<$ red deer) and site conditions (e.g. Gill 1992). Typically, the more severe the browsing (or clipping) was, the smaller the height increment, the larger the difference in height between browsed and unbrowsed trees, the lower the aboveground biomass (cf. Tables 2, 3, and e.g. Canham et al. 1994; Edenius et al. 1993; Kristöfel and Pollanschütz 1995; Crouch 1966; Chaar et al. 1997) and the lower the seed production (e.g. Bergström and Danell 1987). Neither heavily browsed nor suppressed and "moderately" browsed saplings are probably able to compensate for height loss caused by (artificial) browsing (cf. this study but see also Kupferschmid and Bugmann 2013). Therefore, we recommend integrating a measure of "feeding strength" into the assessment of browsing. An additional measure of tree vigour would strongly enhance the value of such assessments. As A. alba is very shade-tolerant, managing for more light alone is unlikely to lead to a substantially better reaction. On the contrary, A. alba saplings have many competitive advantages under somewhat shaded conditions (Paluch 2005), i.e. under little more than $10 \%$ site openness (see our study or Kupferschmid et al. 2013, 2014; Szymura et al. 2007).

Acknowledgments We thank Adolf Tschudi and Hanspeter Mariacher and all the other forestry workers from the municipality of Glarus Süd (formerly Schwanden) for their help with the fence construction and repair and planting of $A$. alba saplings, as well as many inspiring discussions. We are grateful to Stephan Zimmermann and Marco Walser from the Swiss Federal Institute for Forest, Snow and Landscape Research WSL in Birmensdorf, Switzerland, for their help with the soil profile and with the soil and needle analysis. We thank Silvia Dingwall for language revision. The work of the first author was funded by the Swiss Federal Office for the Environment under the project "Langfristige Walddynamik unter Ungulaten-Einfluss", Contract No. 00.0138.PZ/H362-1153. 


\section{References}

Ammer C (1996) Impact of ungulates on structure and dynamics of natural regeneration of mixed mountain forests in the Bavarian Alps. For Ecol Manag 88(1-2):43-53

Ayres E, Heath J, Malcolm P, Black HIJ, Kerstiens G, Bardgett RD (2004) Tree physiological responses to above-ground herbivory directly modify below-ground processes of soil carbon and nitrogen cycling. Ecol Lett 7:469-479

Baraza E, Zamora R, Hodar HA, Gomez JM (2007) Plant-herbivore interaction: beyond a binary vision. In: Pugnaire F, Valladares $\mathrm{F}$ (eds) Functional plant ecology, 2nd edn. CRC Press, Boca Raton, pp 481-514

Bergquist J, Bergström R, Zakharenka A (2003) Responses of young Norway spruce (Picea abies) to winter browsing by roe deer (Capreolus capreolus): effects on height growth and stem morphology. Scand J For Res 18(4):368-376

Bergström R, Danell K (1987) Effects of simulated winter browsing by moose on morphology and biomass of two birch species. J Ecol 75:533-544

Canham CD, McAninch JB, Wood DM (1994) Effects of the frequency, timing and intensity of simulated browsing on growth and mortality of tree seedlings. Can J For Res 24(4):817-825

Cary Institute of Ecosystem Studies (1999) Gap light analyzer (GLA). Simon Fraser University, Institute of Ecosystem Studies. http:// www.caryinstitute.org/discover-ecology

Chaar H, Colin F, Leborgne G (1997) Artificial defoliation, decapitation of the terminal bud, and removal of the apical tip of the shoot in sessile oak seedlings and consequences on subsequent growth. Can J For Res 27(10):1614-1621

Chapin FS, Johnson DA, McKendrick JD (1980) Seasonal movement of nutrients in plants of differing growth form in an Alaskan tundra ecosystem: implications for herbivory. J Ecol 68:189-209

Cornelis J, Casaer J, Hermy M (1999) Impact of season, habitat and research techniques on diet composition of roe deer (Capreolus capreolus): a review. J Zool 248:195-207

Crouch GL (1966) Effects of simulated deer browsing on Douglas-fir seedlings. J For 64(5):322-326

Danell K, Bergström R, Edenius L (1994) Effects of large mammalian browsers on architecture, biomass, and nutrients of woody plants. J Mammal 75(4):833-844

Diaci J, Rozenbergar D, Boncina A (2010) Stand dynamics of Dinaric old-growth forest in Slovenia: are indirect human influences relevant? Plant Biosyst 144(1):194-201

Dobrowolska D (2008) Growth and development of silver fir (Abies alba Mill.) regeneration and restoration of the species in the Karkonsze Mountains. J For Sci 54(9):398-408

Edenius L, Danell K, Bergström R (1993) Impact of herbivory and competition on compensatory growth in woody plants: winter browsing by moose on Scots pine. Oikos 66:286-296

Eiberle K (1978) Folgewirkungen eines simulierten Wildverbisses auf die Entwicklung junger Waldbäume. Schweizerische Zeitschrift für Forstwesen 129(9):757-768

Feurdean A, Willis KJ (2008) Long-term variability of Abies alba in NW Romania: implications for its conservation management. Divers Distrib 14(6):1004-1017

Frehner M, Wasser B, Schwitter R (2005) Nachhaltigkeit und Erfolgskontrolle im Schutzwald. Wegleitung für Pflegemassnahmen in Wäldern mit Schutzfunktion. Bundesamt für Umwelt, Wald und Landschaft, Bern

Gabellini B, Screm E (1968) The suitability of various natural substrates to serve as a seedbed for Abies alba and Picea abies. Ann Accad Ital Sci Forest 17:409-440
Garcia-Gonzalez R, Cuartas P (1996) Trophic utilization of a montane/subalpine forest by chamois (Rupicapra pyrenaica) in the Central Pyrenees. For Ecol Manag 88(1-2):15-23

Gebert C, Verheyden-Tixier H (2001) Variations of diet composition of red deer (Cervus elaphus L.) in Europe. Mammal Rev 31(3):189-201

Gill RMA (1992) A review of damage by mammals in north temperate forests: 1 . Deer. Forestry 65(2):145-169

Grassi G, Bagnaresi U (2001) Foliar morphological and physiological plasticity in Picea abies and Abies alba saplings along a natural light gradient. Tree Physiol 21:959-967

Hart JM, Landgren CG, Moody JT, Fletcher RA, Horneck DA (2012) Needle collection time for nutrient evaluation in christmas tree production. Commun Soil Sci Plant Anal 43(1-2):471-477

Häsler H, Senn J (2012) Ungulate browsing on silver fir: the role of occasions, food shortage, and diet preferences. Wildl Biol 18(1):67-74

Häsler H, Senn J, Edwards PJ (2008) Light-dependent growth responses of young Abies alba to simulated ungulate browsing. Funct Ecol 22:48-57

Iason GR, Duncan AJ, Hartley SE, Staines BW (1996) Feeding behaviour of red deer (Cervus elaphus) on sitka spruce (Picea sitchensis): the role of carbon-nutrient balance. For Ecol Manag 88(1-2):121-129

Ignesti S, Paci M (1990) Studi sulla rinnovatione naturale dell'abete bianco nella foresta di Vallombrosa. Accad Ital Sci Forest 89(38):541-584

Klopcic M, Jerina K, Boncina A (2010) Long-term changes of structure and tree species composition in Dinaric uneven-aged forests: are red deer an important factor? Eur J For Res 129:277-288

Klötzli F (1965) Qualität und Quantität der Rehäsung im Wald- und Grünland-Gesellschaften des nördlichen Mittellandes. Veröff Geobot Inst Eidgenöss Tech Hochsch, Stift Rübel Zür Heft 38:1-186

Kolly AC, Kupferschmid AD (2014) Reaktion von Weisstannen auf ein- bis mehrmaligen Verbiss entlang von Lichtgradienten. Schweizerische Zeitschrift für Forstwesen 165(7):198-207

Kristöfel F, Pollanschütz J (1995) Entwicklung von Fichtenpflanzungen nach Triebrückschnitten. FBVA Berichte 85:1-16

Kučeravá B, Dobrovolný L, Remeš J (2013) Responses of Abies alba seedlings to different site conditions in Picea abies plantations. Dendrobiology 69:49-58

Kupferschmid AD, Brang P (2010) Praxisrelevante Grundlagen: Zusammenspiel zwischen Wild und Wald. In: Wald und WildGrundlagen für die Praxis. Wissenschaftliche und methodische Grundlagen zum integralen Management von Reh, Gämse, Rothirsch und ihrem Lebensraum, vol Umwelt-Wissen Nr. 1013. Bundesamt für Umwelt BAFU, Bern, pp 9-39

Kupferschmid AD, Bugmann H (2005) Effect of microsites, logs and ungulate browsing on Picea abies regeneration in a mountain forest. For Ecol Manag 205:251-265

Kupferschmid AD, Bugmann H (2013) Timing, light availability and vigour determine the response of Abies alba saplings to leader shoot browsing. Eur J For Res 132:47-60

Kupferschmid AD, Wasem U (2014) Filme zum Verbiss an Weisstannen. ETH e-collection. http://dx.doi.org/10.3929/ethz-a010075029

Kupferschmid AD, Zimmermann S, Bugmann H (2013) Browsing regime and growth response of naturally regenerated Abies alba saplings along light gradients. For Ecol Manag 310:393-404

Kupferschmid AD, Wasem U, Bugmann H (2014) Light availability and ungulate browsing determine growth, height and mortality of Abies alba saplings. For Ecol Manag 318:359-369

Långström B, Hellqvist C (1992) Height growth recovery and crown development in top-damaged Pinus sylvestris trees. Scand J For Res 7:237-247 
Metzger FT (1977) Sugar maple and yellow birch seedling growth after simulated browsing. U S Forest Service Research Paper NC 140:1-6

Millard P (1995) Ecophysiology of internal cycling of nitrogen for tree growth. Z Pflanzenernähr Bodenk 159:1-10

Millard P, Hester AJ, Wendler R, Wendler B (2001) Interspecific defoliation responses of trees depend on sites of winter nitrogen storage. Funct Ecol 15:535-543

Mitscherlich G, Weise U (1982) Die Fichten-Hemmungsversuche in Abtsgmünd (Fi 304) und Crailsheim (Fi 348). Allg Forst Jagdztg 153(6):97-104

Moser B, Schütz M, Hindenlang K (2006) Importance of alternative food resources for browsing by roe deer on deciduous trees: the role of food availability and species quality. For Ecol Manag 226:248-255

Mosteller F, Tukey JW (eds) (1977) Data analysis and regression: a second course in statistics. Behavioral science: quantitative methods. Addison-Wesley, Reading

Müller P, Zopfi P (1999) Vom Wildschutz zum Naturschutz. In: 450 Jahre Freiberg Kärpf. Neujahrsbote 1999 für das Glarner Hinterland. Verlag Neujahrsbote, Linthal, pp 11-17

Muscolo A, Sidari M, Bagnato S, Mallamaci C, Mercurio R (2010) Gap size effects on above- and below-ground processes in a silver fir stand. Eur J For Res 129:355-365

Mutch F (2000) Empfehlungen für die sachgerechte Düngung von Christbaumkulturen. vol 10-NOV-2000. http://bfw.ac.at/300/ 1275.html

Nobis M (2005) SideLook 1.1-Imaging software for the analysis of vegetation structure with true-colour photographs. http://www. appleco.ch

Odermatt O, Wasem U (2008) Verbiss an Tannen erst Ende März? Wald und Holz 89(10):25

Onderscheka K, Reimoser F, Tataruch F, Steineck T, Klansek E, Völk F, Willing R, Zandl J (1989) Integrale Schalenwildbewirdschaftung im Fürstentum Liechtenstein unter besonderer Berücksichtigung landschaftsökologischer Zusammenhänge, vol Band 11. Naturkundliche Forschung im Fürstentum Liechtenstein, Vaduz

Osterloher A, Wiechmann R (1993) Verbissbelastung durch Schalenwild: zur unterschiedlichen Verbisstoleranz der Baumarten. Allg Forstztg (Wien) 22:1159-1160

Paluch JG (2005) The influence of the spatial pattern of trees on forest floor vegetation and silver fir (Abies alba Mill.) regeneration in uneven-aged forests. For Ecol Manag 205:283-298

Pépin D, Renaud P-C, Boscardin BY, Goulard M, Mallet C, Anglard F, Ballon P (2006) Relative impact of browsing by red deer on mixed coniferous and broad-leaved seedlings: an enclosurebased experiment. For Ecol Manag 222(1-3):302-313
Price PW (1991) The plant vigor hypothesis and herbivore attack. Oikos 62:244-251

Priewasser K, Bachofen H, Wohlgemuth T (2013) Soil pH and ground vegetation are major predictors of tree regeneration in large forest gaps 10 and 20 years after windthrow in Central Europe. In: Priewasser K (ed) PhD Thesis, Department of Environmental System Science. ETH Zürich, Zürich

R Development Core Team (2011) R: A language and environment for statistical computing. R Foundation for Statistical Computing, Vienna, Austria. http://www.R-project.org

Robakowski P, Montpied P, Dreyer E (2003) Plasticity of morphological and physiological traits in response to different levels of irradiance in seedlings of silver fir (Abies alba Mill). Trees 17:431-441

Senn J, Suter W (2003) Ungulate browsing on silver fir (Abies alba) in the Swiss Alps: beliefs in search of supporting data. For Ecol Manag 181(1-2):151-164

Shipley LA, Illius AW, Danell K, Hobbs NT, Spalinger DE (1999) Predicting bite size selection of mammalian herbivores: a test of a general model of diet optimization. Oikos 84:55-68

Stancioiu PT, O'Hara KL (2006) Regeneration growth in different light environments of mixed species, multiaged, mountainous forest of Romania. Eur J For Res 125:151-162

Stauffer HB (2008) Contemporary bayesian and frequentist statistical research methods for natural resource scientists. Wiley, Hoboken, New Jersey

Szymura TH, Dunajski A, Aman I, Makowski M, Szymura M (2007) The spatial pattern and microsites requirements of Abies alba natural regeneration in the Karkonosze Mountains. Dendrobiology 58:51-57

Tan BS, Bruckert S (1992) Effect of physical environmental factors on the initial stages of the natural regeneration of fir (Abies alba) at some sites in the Jura. Ann Sci For 49(4):337-349

Tixier H, Duncan P (1996) Are European roe deer browsers? A review of variations in the composition of their diets. Rev Ecol Terre Vie 51:3-17

Vandenberghe C, Freléchoux F, Buttler A (2008) The influence of competition from herbaceous vegetation and shade on simulated browsing tolerance of coniferous and deciduous saplings. Oikos 117:415-423

Weber E (1967) Versuche zur Naturverjüngung der Weisstanne (Abies alba Mill.) im Bereich der Oberforstdirektion Regensburg. Forstwiss Cbl 86:221-238

Welch D, Staines BW, Scott D, French DD (1992) Leader browsing by red and roe deer on young Sitka spruce trees in western Scotland. II. Effects on growth and tree form. Forestry 65:309-330 